\title{
Human pluripotent stem cells in regenerative medicine: where do we stand?
}

\author{
Ha Thi Nguyen ${ }^{1}$, Kurt Jacobs ${ }^{2}$ and Claudia Spits ${ }^{3}$ \\ ${ }^{1}$ Center for Molecular Biology, Institute of Research and Development, Duy Tan University, Danang, Vietnam, \\ ${ }^{2}$ Institute of Molecular Cancer Research, University of Zurich (UZH), Zurich, Switzerland and ${ }^{3}$ Research Group \\ Reproduction and Genetics, Faculty of Medicine and Pharmacy, Vrije Universiteit Brussel (VUB), Brussels, Belgium
} Correspondence should be addressed to C Spits; Email: Claudia.Spits@vub.be

\begin{abstract}
Human pluripotent stem cells have the capacity to self-renew indefinitely and the ability to differentiate into all cell types of a human body. These characteristics instill them with an enormous promise in regenerative medicine, where they could be used in cell, tissue and even organ-based replacement therapy. In this review, we discuss their potential clinical applications and the advantages and pitfalls for the different types of human pluripotent stem cells to transition from the bench to the bedside. We provide an overview of the current clinical trials, and the specific challenges we are still facing, including immune compatibility, suboptimal differentiation, risk of tumor formation and genome instability.

Reproduction (2018) 156 R143-R153
\end{abstract}

Human pluripotent stem cells (hPSC) have an unlimited capacity to self-renew and can differentiate into cells of all three embryonic germ layers, making them very appealing to the fields of regenerative medicine and in vitro disease modeling. There are two types of hPSC: human embryonic stem cells (hESC) and humaninduced pluripotent stem cells (hiPSC). The first are derived from early human embryos, while the second are obtained by reprogramming of somatic cells. By now, the derivation and culture of hPSC have found its way into many laboratories worldwide (Löser et al. 2010, Fraga et al. 2011), and these cells have become the basis of a very active research domain. The European Human Embryonic Stem Cell Registry contains 738 hESC and 1.822 hiPSC lines from 251 providers of 29 countries (http://www.hescreg.eu; Monthly Statistic Report To 01.08.2018), and, for instance, a PubMed search using the term 'human pluripotent stem cells' on 8/08/2018, yielded 27.179 results.

\section{The first steps of $\mathrm{hPSC}$ in regenerative medicine}

The greatest therapeutic promise of hPSC is to cure individuals by replacement of somatic cells that were lost as a result of degenerative disorders or injury (Fig. 1). To date, hPSCs have been successfully differentiated into virtually all cell types, with the exception of functional gametes, and are being considered for the treatment of numerous conditions, such as neurodegenerative diseases, macular degeneration, cardiac failure and type I diabetes mellitus (Trounson \& DeWitt 2016).
Tissues and organs with a more complex organization are more difficult to obtain, although different groups have developed hPSC-derived organoid cultures that recapitulate the inner ear, retina, brain, lung, kidney, pituitary gland, liver, small intestine and stomach (reviewed in Kretzschmar \& Clevers 2016). Of these, some of the most remarkable examples are the organoids with human brain structures (Lancaster et al. 2013, Renner et al. 2017), the renal tissues with a kidney-like organization (Takasato et al. 2014, Morizane et al. 2015) and the retinal organoids (DiStefano et al. 2018, Li et al. 2018, Mclelland et al. 2018). Nevertheless, although these developments are very exciting, the clinical translation of hPSC is just kicking off. Table 1 provides an overview of the ongoing and completed clinical trials using hPSC-derived cell types.

Neural cell types were among the first to be obtained through directed differentiation of hESC. The first clinical trial of hPSC was a safety trial using hESC-derived oligodendrocyte progenitor cells to treat spinal cord injury. It was initiated in October 2010 by the Geron Corporation and halted 1 year later due to a change in business strategy, after transplantation of five patients who were either paraplegic or quadriplegic. This clinical trial was later taken over by Asterias Biotherapeutics Inc. and completed. The therapy caused no adverse events, but also no motor or sensory neurological improvements were observed (Ilic et al. 2015). More recently, the company initiated a new phase $1 / 2$ a dose escalation study using the oligodendrocyte progenitor cells in patients with cervical spinal cord injury. Last 


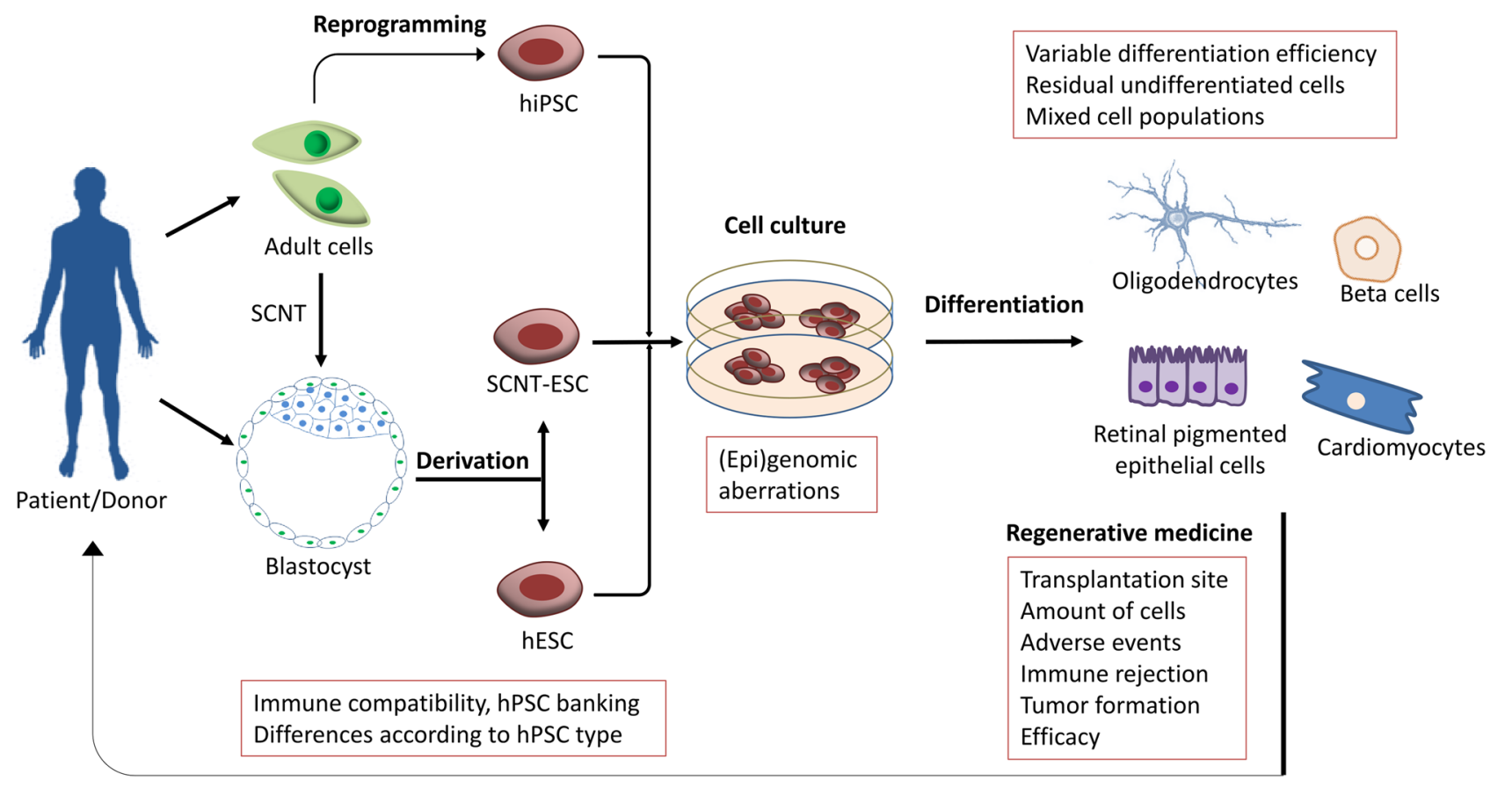

Figure 1 The potential applications of human pluripotent stem cells and the challenges in bringing them from the bench to the bedside. The figure illustrates the different steps in the process, from the derivation of hPSC lines to the transplantation of their differentiated progeny. HPSC can be obtained from donated human blastocysts (human embryonic stem cells, hESC), from blastocysts obtained by somatic cell nuclear transfer (SCNT-ESC) and by somatic cell reprogramming (induced pluripotent stem cells, hiPSC). These last two types are by definition immune compatible with the donor of the somatic cells. The cells are then kept in culture to obtain sufficient cells to initiate differentiation. The terminally differentiated cells may be used in regenerative medicine. The main current challenges in this process are indicated in red boxes. These include the choice among the different hPSC and immune compatibility, the susceptibility of hPSC to genome instability during prolonged culture, suboptimal differentiation and the complications arising during regenerative medicine.

year, the company reported that 9 months after the treatment, three out of six of their patients showed motor level recovery of at least two levels. Patients without the treatment show comparable spontaneous recovery in $26 \%$ of cases (http://asteriasbiotherapeutics.com/).

The vast majority of the currently ongoing hPSCbased clinical trials involve the use of retinal pigmented epithelial (RPE) cells derived from hESC, hiPSC and somatic cell nuclear transfer (SCNT)-ESC to restore or improve vision in patients suffering from retinal degenerative diseases including acute age-related macular degeneration (AMD) and Stargardt's macular dystrophy (SMD) (Table 1; Schwartz et al. 2012, 2015, Diniz et al. 2013, Song et al. 2015, Mandai et al. 2017). These diseases are characterized by a loss of RPE cells, which leads to the death of the photoreceptors causing loss of vision. The human eye has become the favored testing ground for hPSC-based therapies for several reasons. Particularly, the eye is an immunoprivileged site, it is easy to monitor and the current RPE differentiation protocols are very robust and yield a pure cell population.

In 2013, the Riken Center for Developmental Biology initiated the first clinical research involving the use of hiPSC-derived cells in humans. A first patient suffering from AMD was transplanted with RPEs generated using
hiPSC derived from her own skin cells. Unfortunately, the study was suspended in 2015 due to the identification of potentially harmful mutations in the second candidate's hiPSC and the RPE cells derived from them (Mandai et al. 2017). The first successfully completed phase I clinical trial with hESC-derived cells concluded on September 2014 in England with the transplantation of hESC-derived RPE sheets into 18 patients, nine affected with AMD and nine with SMD. The clinical trial did not only show the feasibility and safety of the procedure but also revealed an increase in the sub-retinal pigmentation in 13 out of 18 treated patients (Schwartz et al. 2015), and an improvement in visual acuity of at least 15 letters in eight of 18 patients during the first year after surgery, with no adverse effects seen in any of them (Schwartz et al. 2015).

A third ectodermal cell type that is making its way into the clinical trials are stem cell-derived dopaminergic neurons and neural precursor cells for the treatment of Parkinson's disease. Parkinson's disease is a neurodegenerative disorder caused by the death of ventral mesencephalic dopaminergic neurons. Transplantation of fetal dopaminergic neurons in Parkinson's disease patients, although yielding variable success, has demonstrated the feasibility of cell-based therapy in this disease. Over the years, several groups have proven that 
hPSC are a potentially sound source of this specific cell type, and several pre-clinical studies have been carried out in rodent and primate models (reviewed in Lindvall 2016). Very recently, the Chinese Academy of Sciences, in collaboration with the first affiliated hospital of Zhengzhou university, have started a phase I/II, openlabel study to assess the safety and efficacy of striatum transplantation of hESC-derived neural precursor cells in patients with Parkinson's disease. Specifically, the study will enroll 50 patients for cell injection, administering a single dose of neural precursor cells by stereotaxic intrastriatal injection (Wang et al. 2018).

Human ESC-derived cardiomyocytes have been successfully obtained either by directed differentiation (Laflamme et al. 2007) or via embryoid bodies formation (Caspi et al. 2007). They are also being investigated for the clinical application to support heart regeneration, and pre-clinical studies in small-animal models such as mice and rats have shown favorable results (Caspi et al. 2007, Shiba et al. 2012). Using a non-human primate model of myocardial ischemia, Chong et al. reported that these cells appear to fully integrate and regenerate infarcted hearts (Chong et al. 2014). Menasché and coworkers started a phase I clinical trial for transplantation of purified CD $15^{+} \mathrm{ISI}-1^{+} \mathrm{hESC}$-derived cardiac progenitors to six patients. A median dose of 8.2 million of highly purified hESC-derived cardiovascular progenitors were embedded in a biocompatible fibrin patch and transplanted into the infarcted area of the heart of patients with severely impaired cardiac function when the patients undergo scheduled coronary artery bypass surgery or mitral valve procedures (Menasché et al. 2014). This clinical trial was recently completed and demonstrated the technical feasibility of producing clinical-grade hESC-derived cardiovascular progenitors and supports their short- and medium-term safety, thereby setting the grounds for adequately powered efficacy studies (Menasché et al. 2018).

Another application that has reached the clinical trials is the use of hESC-derived pancreatic beta cells or pancreatic precursors to treat individuals with type 1 diabetes. Different research groups have obtained pancreatic endoderm that can efficiently generate glucose-responsive, insulin-secreting endocrine cells after transplantation (Kroon et al. 2008, Sui et al. 2013, Kirk et al. 2014, Pagliuca et al. 2014). ViaCyte Inc., a biotech company working on the development of a stem cell therapy for treatment of type 1 diabetes, optimized a protocol for the scalable production of functional pancreatic progenitors from hESC (Schulz et al. 2012). Their approach is based on delivering pancreatic precursor cells subcutaneously in a device with a selectively porous cell-impermeable membrane. These precursor cells are designed to further differentiate and mature in vivo after surgical implantation, not only to fully functioning insulin-producing beta cells but also to other endocrine cell types that make up the normal human pancreatic islet (Kirk et al. 2014). An alternative approach is the generation of islet-like organoids from hESC that are functionally capable of glucose-responsive insulin secretion as well as therapeutic effects (Kim et al. 2016). Recently, Ameri and coworkers have identified GP2 as a specific marker of human pancreatic endoderm cells and demonstrated that GP2 ${ }^{+}$pancreatic endoderm cells efficiently differentiate into glucose-responsive insulin-producing cells. Isolation of the target cells using this cell surface marker has a further advantage that it can help to eliminate the residual undifferentiated hESC, thus offering a safer route toward the manufacture of endocrine cells for therapy (Ameri et al. 2017).

\section{The challenging side of hPSC}

Despite the first successes in closing the gap between the bench and bedside, there is still a number of significant hurdles to overcome for hPSC to reach their full and safe clinical potential. Figure 1 illustrates each challenge at the different steps from hPSC derivation to their transplantation to the patient. In the next sections, we discuss the most significant issues in detail.

\section{Ethical issues}

The main reservation that has been raised against the use of hESC is based on ethical grounds because the derivation of these cells requires the use of human embryos (Rosner et al. 2014). Conversely, it is possible to obtain hESC from single blastomeres of cleavagestage embryos, this being a potential embryo-sparing approach (Klimanskaya et al. 2006, Geens et al. 2009). In this setting, one blastomere is biopsied from the embryo in the same manner as done for pre-implantation genetic diagnosis. While this blastomere could be then used to establish a hESC line, the rest of the embryo could further develop and be transferred to the patient. On the other hand, although technically possible, this approach is practically inviable, because it requires patients undergoing a fertility treatment to agree to a blastomere biopsy on their embryos, potentially compromising their chances of becoming pregnant.

\section{Immune compatibility: hESC, SCNT-ESC and hiPSC}

A second issue raised on the use of hESC for transplantation was the risk of immune rejection since they are allogeneic to the patients (Zhan et al. 2004, Simonson et al. 2015). Currently, there are two options to solve this problem. The first appeared with the development of cell reprogramming (Takahashi \& Yamanaka 2006, Takahashi et al. 2007). Human iPSC are reprogrammed directly from patients' somatic cells, and thus circumvent embryo destruction to establish hPSC lines and generate autologous hPSC. The second approach is the use of SCNT to generate patient-specific 


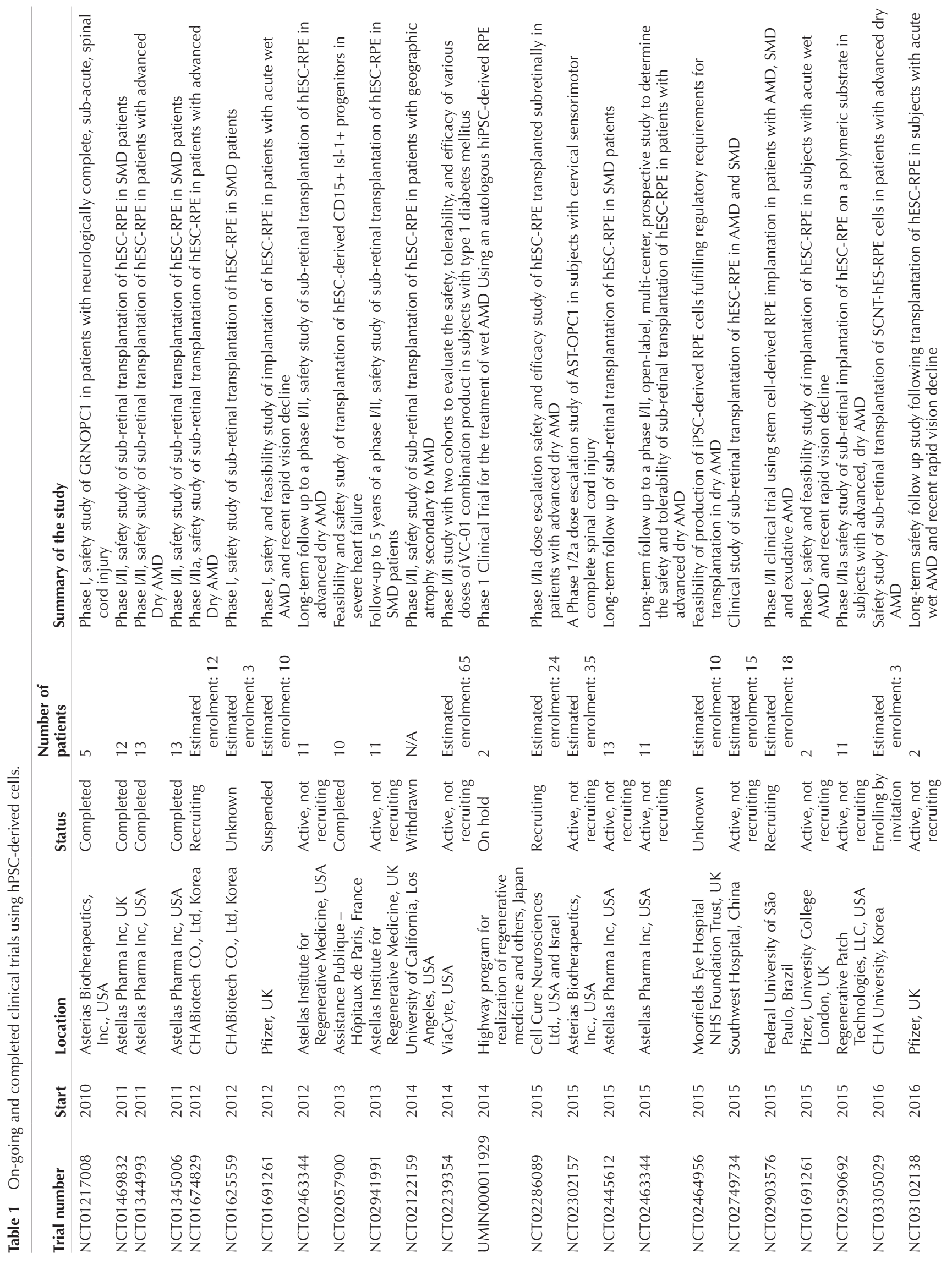




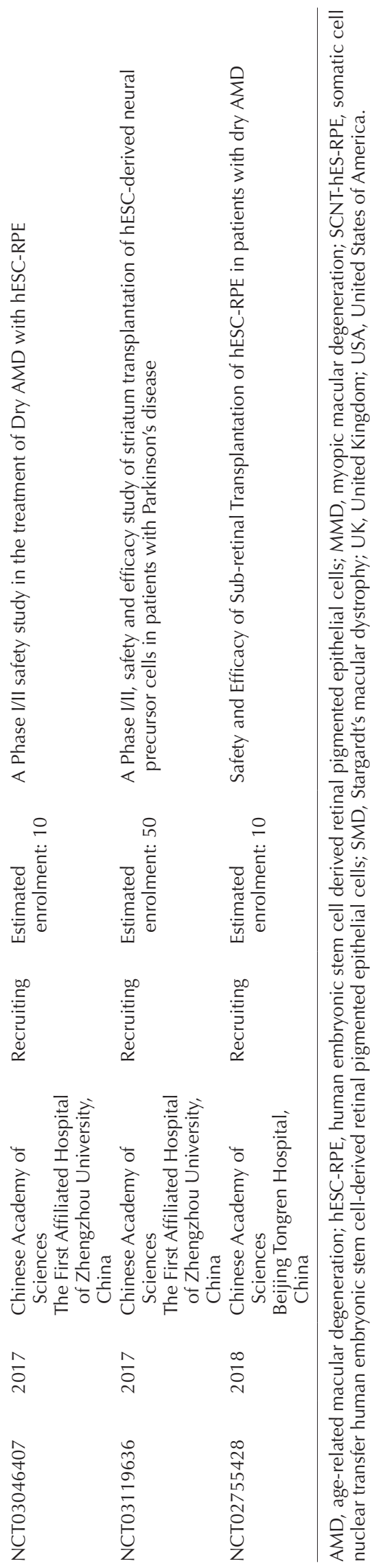

hESC lines (Tachibana et al. 2013, Chung et al. 2014). In this context, SCNT is performed by transferring the nucleus of a somatic cell to an enucleated human oocyte and the resulting embryos are then used for the derivation of ESC (SCNT-ESC) lines. It is important to keep in mind that SCNT is technically very challenging, and the derivation of ESC lines from human SCNT embryos has only recently been achieved (Tachibana et al. 2013, Chung et al. 2014).

Despite the strong similarities between hESC, hiPSC and SCNT-ESC, there is still debate on whether these cells are indeed equivalent both in biological terms and suitability for clinical applications (reviewed in Wolf et al. 2017). There are two main issues being discussed, namely (i) the differences in transcriptional and epigenetic landscape and (ii) the potential differences in mutational burden between these cells. For instance, Ma and coworkers compared genetically matched sets of hiPSC and SCNT-ESC to hESC and showed that the DNA methylation and transcriptional signatures of SCNT-ESC and hESC were remarkably similar and at the same time distinct to those of hiPSC, suggesting that SCNT-ESC undergoes more complete reprogramming than hiPSC (Ma et al. 2014). Using a similar approach, Johannesson et al. reported that gene expression and DNA methylation profiles of SCNT-ESC and hiPSC are similar (Johannesson et al. 2014). These contradictory results could be possibly partly explained by the use of different donor cell types, reprogramming methods and even time in culture, as the reprogramming process takes longer than first thought, and the cell lines settle in their pluripotent state with time (reviewed in Yoshihara et al. 2017a).

\section{The cost of autologous hPSC}

Despite the initial appeal of generating autologous hPSC for regenerative medicine, it is a non-neglectable issue that the generation of patient-specific hiPSC or SCNT-ESC would create a very expensive and lengthy treatment. This has made the use of hPSC banks for allogeneic treatment more appealing and realistic. In this line, scientists from Kyoto University have been establishing an hiPSC bank containing multiple clinical-grade hiPSC lines from donors homozygous for three human leukocyte antigens (HLA) loci: HLAA, $-B$ and -DR. This allows optimized matching with patients, reducing the degree of immune rejection of the allogeneic transplants (Masuda et al. 2014, Azuma \& Yamanaka 2016). Different studies estimate that to offer an HLA-matched transplant to $90 \%$ of the Japanese population, a cell bank size of 50 (Nakatsuji et al. 2008) up to 140 (Okita et al. 2011) homozygous hiPSC lines would suffice. For a hESC bank, on the other hand, lines derived from 170 randomly selected donated embryos would provide at least one hESC line with a single mismatch at one locus or better match for $80 \%$ of patients (Nakajima et al. 2007). 


\section{Suboptimal differentiation}

Another important issue is that the vast majority of differentiation protocols are not yet fully optimized. Most differentiation protocols result in a heterogeneous population of cells, frequently with only a small fraction of the desired cell type (D'Amour et al. 2006, Mfopou et al. 2010, Efthymiou et al. 2014). Often, these protocols try to mimic the microenvironment provided by the embryo. However, our understanding of these processes is still incomplete, and despite the use of matrices and specific growth factors to support the cells, the difference between the 3D environment of the embryo and the culture dish is still large. A strategy to partially counter this problem would be to derive and transplant progenitor cells rather than the fully differentiated cells (Kirk et al. 2014), assuming that the in vivo environment will assist the final differentiation steps. A further complication is added by the fact that many differentiation protocols show a wide variation in efficiency depending on which hPSC line is used as starting material. The leading hypothesis for these biases is genetic and epigenetic differences between the hPSC lines (extensively reviewed in Keller et al. 2018).

The epigenetic factor has received particular attention in hiPSC, with the idea of epigenetic memory. This concept stems from a number of works that investigated the differences in differentiation capacity of hiPSC and described them to epigenetic marks inherited from the cells of origin and that had not been correctly reset during the reprogramming process (Bar-Nur et al. 2011, Kim et al. 2011, Ohi et al. 2011). However, current knowledge suggests that the reprogramming process itself is prone to inducing epigenetic abnormalities (Tiemann et al. 2016) and that the main factor influencing the differentiation propensity is not an epigenetic memory as such, but the (epi)-genetic background of the donor of the source cells (reviewed in Keller et al. 2018).

The state of pluripotency of PSC lines is also emerging as an important inducer of differentiation bias. In mouse, ESC can exist in two states depending on the development stage of the embryos used for the derivation. Mouse naïve or ground state ESCs are derived from pre-implantation embryos, while mouse primed-state ESC are derived from post-implantation embryos. These two mouse ESC types have very different characteristics, including a lower differentiation bias in mouse-naïve ESC. In the human, hESC are derived only from pre-implantation embryos, but molecular analyses show that hESC are more similar to mouse primedstate ESC than to mouse-naïve ESC (Tesar et al. 2007, Nichols \& Smith 2009, Hanna et al. 2010). Currently, the derivation of human-naïve ESC is possible through different methods, including the ectopic overexpression of the transcription factors and the use of tailored culture systems (reviewed in Weinberger et al. 2016). The most important advantage to human-naïve ESC is that they should display stable self-renewal capacity and survival, allowing efficient cell expansion and differentiation, and show less differentiation bias (Honda et al. 2013, Duggal et al. 2015). However, recent studies have confronted this notion by showing that naïve hPSC display a reduction in differentiation capacity and an increase in differentiation bias compared to the primed hPSC (Lee et al. 2017, Warrier et al. 2017). Furthermore, naïve hPSC would fail to generate mature cells, in contrast to their primed counterparts (Warrier et al. 2017).

An important problem caused by imperfect differentiation is the persistence of residual undifferentiated cells that may lead to tumor formation upon transplantation (Fujikawa et al. 2005, Blum \& Benvenisty 2008, Sui et al. 2013). Even small numbers of remaining undifferentiated cells can lead to tumor formation (Lee et al. 2009) or the growth of immature tissues (Roy et al. 2006), making the achievement of a pure differentiated population of desired cell type prior to transplantation prerequisite. Several different attempts have been made to reduce the frequency of teratoma formation after transplantation, such as eliminating the residual undifferentiated cells by flow cytometry (Tang et al. 2011, Quintanilla et al. 2014), extending the in vitro differentiation culture period (Brederlau et al. 2006, Doi et al. 2012), reducing the number of transplanted cells (Lee et al. 2009) or treating the cell suspensions with agents that are specifically cytotoxic to undifferentiated cells prior to transplantation (Choo et al. 2008, Ben-David et al. 2013, Lee et al. 2013, Rosner et al. 2014, Mitsui et al. 2015). Nevertheless, and despite these efforts to eliminate these cells from the final differentiated product, the best solution would be to identify and tackle the causes of why these residual cells stay undifferentiated.

\section{Genome instability}

There is significant concern about the genetic and epigenetic integrity of hPSC. The increasing body of knowledge on this topic has shown that, up to now, it appears that any aspect of the genome of hPSC that is investigated, reveals forms de novo mutagenesis and instability.

It is by now well established that hPSCs that acquire chromosomal abnormalities that offer them with a selective advantage will outgrow and eventually take over the culture (reviewed in Lund et al. 2012, Nguyen et al. 2013). For example, more than $20 \%$ of the hPSC lines worldwide show a gain of a small region of 20q11.21 (Amps et al. 2011), which leads to overexpression of $B C L 2 L 1$ ( $\mathrm{BCl}-\mathrm{xL}$ ), inhibiting the mitochondrial apoptosis pathway and conferring a strong selective advantage to the mutant cells (Avery et al. 2013, Nguyen et al. 2014). Remarkably, the 20q11.21 amplification is also common in cancer (Scotto et al. 2008, Beroukhim et al. 2010, Tabach et al. 2011), illustrating the link between culture 
adaptation and malignancy. For the other common chromosomal abnormalities appearing in hPSC after prolonged culture (such as gains of chromosomes 1, 12 and 17), the driver genes have not yet been conclusively established. The most compelling evidence is for the gain of chromosome 12, where the smallest common region of gain comprises the pluripotency regulator NANOG (Draper et al. 2004, Mayshar et al. 2010, Ben-David et al. 2014). HPSCs carrying this gain show decreased differentiation capacity and their gene expression profiles are similar to that of germ cell tumors and cells transgenically overexpressing NANOG (BenDavid et al. 2014).

Although the subject of much research, what causes and modulates the spontaneous mutagenesis of hPSC in culture has not yet been fully understood. It is known that hPSC undergo significant DNA damage in culture, resulting in different chromosomal gains and losses in individual cells, leading to mosaic cell populations (Jacobs et al. 2014), and it has been repeatedly suggested that hPSC culture conditions may play a significant role in this process. The two most investigated factors have been the method of passaging and the oxygen tension in the incubators. A number of reports have shown that aneuploidy more commonly appears when using enzymatic or chemical passaging methods (Buzzard et al. 2004, Draper et al. 2004, Ravi et al. 2005, Imreh et al. 2006), and that room oxygen tension results in an increase in spontaneous chromosome breaks and gross structural rearrangements (Forsyth et al. 2006, Lim et al. 2011). Recently, culture medium has been identified as a major influence on DNA damage and genomic instability (Jacobs et al. 2016, Bangalore et al. 2017). High-density culture in KnockOut Serum Replacement (KnockOut SR) containing media and on mouse feeders results in medium acidification, leading to increased DNA damage and chromosome abnormalities (Jacobs et al. 2016). Conversely, cells grown in mTeSR and Essential 8 media show higher levels of genotoxic stress and DNA sequence changes than their counterparts grown in KnockOut SR medium (Bangalore et al. 2017). Additionally, aneuploidy as such appears to also make the cells more prone to further genomic instability, due to DNA replication stress, resulting in defective chromosome condensation and segregation (Lamm et al. 2016).

Next to acquired chromosomal changes, hiPSC have two additional sources of loss of genetic integrity: the reprogramming process and the genetic variation in the source cells, originating from somatic mutagenesis (reviewed in Yoshihara et al. 2017a). The first reports on the appearance of de novo CNVs, mostly deletions, in early passage hiPSC suggested that these mutations appeared during reprogramming process and that they progressively disappeared from the culture due to their deleterious effect on the cells (Hussein et al. 2011, Laurent et al. 2011). Later work showed, though, that at least half of these already existed as low-frequency variants in the source cells (Abyzov et al. 2012). Point mutations have also been repeatedly reported in hiPSC (Gore et al. 2011, Ji et al. 2012, Young et al. 2012, Sugiura et al. 2014, Araki et al. 2017, Yoshihara et al. 2017b), and there is evidence that their genome has significantly higher point mutation rates as compared to that of hESC (Sugiura et al. 2014). Here again, the point mutations are suggested to have either pre-existed in the parental somatic cells or to be reprogramming associated (Gore et al. 2011, Ji et al. 2012, Young et al. 2012) and particularly occurring during the initiation step of cell lineage conversion (Sugiura et al. 2014, Araki et al. 2017, Yoshihara et al. 2017b). By all accounts, this significant level of point mutations is concerning, particularly when bearing in mind that both hESC and hiPSC, in the undifferentiated and differentiated state, have been recurrently found to carry TP53 missense mutations (Merkle et al. 2017). The consequences of this in the setting of regenerative medicine are potentially very damaging, as illustrated by the halted RIKEN clinical trial, upon identifying undisclosed genetic variants in their hPSC-derived cells (Garber 2015).

Finally, a last aspect that highlights how the somatic origin of hiPSC hampers their genetic integrity, are the findings regarding their mitochondrial genome. HESC show few variants in their mitochondrial DNA (mtDNA), at relatively low heteroplasmic loads, and are either inherited, or acquired during prolonged in vitro culture, but rarely are of high pathogenic potential (Maitra et al. 2005, Zambelli et al. 2018). In contrast, hiPSCs can display very high heteroplasmic loads of pathogenic mutations. By now, several groups have shown that these variants are found in the source cells (Mah et al. 2011, Kang et al. 2016, Perales-Clemente et al. 2016, Zambelli et al. 2018), that they originate from somatic mutagenesis, and correlate to the age of the cell donor (Kang et al. 2016). Although it is unclear what the exact impact of these mutations is on the functionality of the cells, studies from the field of disease modeling have provided evidence that they may induce defects in differentiation capacity and functionality of hPSC and hPSC-derived cells (Cherry et al. 2013, Folmes et al. 2013, Hatakeyama et al. 2015).

Taken together, there is substantial evidence indicating a susceptibility of hPSC to acquire mutations analogous to those found in cancers. Culture conditions during derivation, expansion and differentiation should be further optimized in such way that genetic instability is minimized, and hPSC and their derivatives should be subjected to genome-wide analyses, especially before clinical application, to avoid transplantation of what could be pre-cancerous cells. It is also clear that there is a lack of systematic studies addressing the risk of these mutations, and there are no guidelines to which clinicians and researchers can adhere (Andrews et al. 2017). At the moment, the COSMIC (Catalogue 
of Somatic Mutations In Cancer) database and the Shibata list from the Pharmaceuticals and Medical Devices Agency in Japan (http://www.pmda.go.jp/ files/000152599.pdf\#page=8) are the two suggested resources to predict the functionality of these variants and assess their potential impact on the safety of these cells.

\section{Conclusions}

Although holding the great potential in regenerative medicine, there is still a big gap to be filled for hPSC to reach their full potential. This review has provided an overview on the potential clinical applications, and the advantages and drawbacks of the different types of hPSC to transition from the bench to the bedside. In addition, we have also discussed the specific challenges that still need to be overcome, including immune compatibility, suboptimal differentiation, risk of tumor formation and genome instability in order to bring hPSC closer to the clinic.

\section{Declaration of interest}

The authors declare that there is no conflict of interest that could be perceived as prejudicing the impartiality of this review.

\section{Funding}

This research did not receive any specific grant from any funding agency in the public, commercial or not-for-profit sector.

\section{References}

Abyzov A, Mariani J, Palejev D, Zhang Y, Haney MS, Tomasini L, Ferrandino AF, Belmaker LAR, Szekely A, Wilson M et al. 2012 Somatic copy number mosaicism in human skin revealed by induced pluripotent stem cells. Nature 492 438-442. (https://doi.org/10.1038/nature11629)

Ameri J, Borup R, Prawiro C, Ramond C, Schachter KA, Scharfmann R \& Semb H 2017 Efficient generation of glucose-responsive beta cells from isolated GP2+ human pancreatic progenitors. Cell Reports 19 36-49. (https://doi.org/10.1016/j.celrep.2017.03.032)

Amps K, Andrews PW, Anyfantis G, Armstrong L, Avery S, Baharvand H, Baker J, Baker D, Munoz MB, Beil S et al. 2011 Screening ethnically diverse human embryonic stem cells identifies a chromosome 20 minimal amplicon conferring growth advantage. Nature Biotechnology 29 1132-1144. (https://doi.org/10.1038/nbt.2051)

Andrews PW, Ben-David U, Benvenisty N, Coffey P, Eggan K, Knowles BB, Nagy A, Pera M, Reubinoff B, Rugg-Gunn PJ et al. 2017 Assessing the safety of human pluripotent stem cells and their derivatives for clinical applications. Stem Cell Reports 9 1-4. (https://doi.org/10.1016/j. stemcr.2017.05.029)

Araki R, Mizutani E, Hoki Y, Sunayama M, Wakayama S, Nagatomo $\mathbf{H}_{\text {, }}$ Kasama Y, Nakamura M, Wakayama T \& Abe M 2017 The number of point mutations in induced pluripotent stem cells and nuclear transfer embryonic stem cells depends on the method and somatic cell type used for their generation. Stem Cells 35 1189-1196. (https://doi.org/10.1002/ stem.2601)

Avery S, Hirst AJ, Baker D, Lim CY, Alagaratnam S, Skotheim RI, Lothe RA, Pera MF, Colman A, Robson P et al. 2013 BCL-XL mediates the strong selective advantage of a 20q11.21 amplification commonly found in human embryonic stem cell cultures. Stem Cell Reports 1 379-386. (https://doi.org/10.1016/j.stemcr.2013.10.005)
Azuma K \& Yamanaka S 2016 Recent policies that support clinical application of induced pluripotent stem cell-based regenerative therapies. Regenerative Therapy 4 36-47. (https://doi.org/10.1016/j. reth.2016.01.009)

Bangalore MP, Adhikarla S, Mukherjee O \& Panicker MM 2017 Genotoxic effects of culture media on human pluripotent stem cells. Scientific Reports 7 42222. (https://doi.org/10.1038/srep42222)

Bar-Nur O, Russ HA, Efrat S \& Benvenisty N 2011 Epigenetic memory and preferential lineage-specific differentiation in induced pluripotent stem cells derived from human pancreatic islet beta cells. Cell Stem Cell 9 17-23. (https://doi.org/10.1016/j.stem.2011.06.007)

Ben-David U, Nudel N \& Benvenisty N 2013 Immunologic and chemical targeting of the tight-junction protein Claudin- 6 eliminates tumorigenic human pluripotent stem cells. Nature Communications 4 1992. (https:// doi.org/10.1038/ncomms2992)

Ben-David U, Arad G, Weissbein U, Mandefro B, Maimon A, Golan-Lev T, Narwani K, Clark AT, Andrews PW, Benvenisty N et al. 2014 Aneuploidy induces profound changes in gene expression, proliferation and tumorigenicity of human pluripotent stem cells. Nature Communications 5 4825. (https://doi.org/10.1038/ncomms5825)

Beroukhim R, Mermel CH, Porter D, Wei G, Donovan J, Barretina J, Boehm JS, Urashima M, Henry KTM, Pinchback RM et al. 2010 The landscape of somatic copy number alteration across human cancers. Nature 463 899-905. (https://doi.org/10.1038/nature08822)

Blum B \& Benvenisty N 2008 The tumorigenicity of human embryonic stem cells. Advances in Cancer Research 100 133-158. (https://doi. org/10.1016/S0065-230X(08)00005-5)

Brederlau A, Correia AS, Anisimov SV, Elmi M, Paul G, Roybon L, Morizane A, Bergquist F, Riebe I, Nannmark U et al. 2006 Transplantation of human embryonic stem cell-derived cells to a rat model of Parkinson's disease: effect of in vitro differentiation on graft survival and teratoma formation. Stem Cells 24 1433-1440. (https://doi. org/10.1634/stemcells.2005-0393)

Buzzard JJ, Gough NM, Crook JM \& Colman A 2004 Karyotype of human ES cells during extended culture. Nature Biotechnology 22 381-382. (https://doi.org/10.1038/nbt0404-381)

Caspi O, Huber I, Kehat I, Habib M, Arbel G, Gepstein A, Yankelson L, Aronson D, Beyar R \& Gepstein L 2007 Transplantation of human embryonic stem cell-derived cardiomyocytes improves myocardial performance in infarcted rat hearts. Journal of the American College of Cardiology 50 1884-1893. (https://doi.org/10.1016/j.jacc.2007.07.054)

Cherry ABC, Gagne KE, Mcloughlin EM, Baccei A, Gorman B, Hartung O, Miller JD, Zhang J, Zon RL, Ince TA et al. 2013 Induced pluripotent stem cells with a mitochondrial DNA deletion. Stem Cells 31 1287-1297. (https://doi.org/10.1002/stem.1354)

Chong JJH, Yang X, Don CW, Minami E, Liu Y-W, Weyers JJ, Mahoney WM, Van Biber B, Cook SM, Palpant NJ et al. 2014 Human embryonic-stemcell-derived cardiomyocytes regenerate non-human primate hearts. Nature 510 273-277. (https://doi.org/10.1038/nature13233)

Choo AB, Tan HL, Ang SN, Fong WJ, Chin A, Lo J, Zheng L, Hentze H, Philp RJ, Oh SKW et al. 2008 Selection against undifferentiated human embryonic stem cells by a cytotoxic antibody recognizing podocalyxinlike protein-1. Stem Cells 26 1454-1463. (https://doi.org/10.1634/ stemcells.2007-0576)

Chung YG, Eum JH, Lee JE, Shim SH, Sepilian V, Hong SW, Lee Y, Treff NR, Choi YH, Kimbrel EA et al. 2014 Human somatic cell nuclear transfer using adult cells. Cell Stem Cell 14 777-780. (https://doi.org/10.1016/j. stem.2014.03.015)

D'Amour KA, Bang AG, Eliazer S, Kelly OG, Agulnick AD, Smart NG, Moorman MA, Kroon E, Carpenter MK \& Baetge EE 2006 Production of pancreatic hormone-expressing endocrine cells from human embryonic stem cells. Nature Biotechnology 24 1392-1401. (https://doi. org/10.1038/nbt1259)

Diniz B, Thomas P, Thomas B, Ribeiro R, Hu Y, Brant R, Ahuja A, Zhu D, Liu L, Koss M et al. 2013 Subretinal implantation of retinal pigment epithelial cells derived from human embryonic stem cells: improved survival when implanted as a monolayer. Investigative Ophthalmology and Visual Science 54 5087-5096. (https://doi.org/10.1167/iovs.1211239.

DiStefano T, Chen HY, Panebianco C, Kaya KD, Brooks MJ, Gieser L, Morgan NY, Pohida T \& Swaroop A 2018 Accelerated and improved differentiation of retinal organoids from pluripotent stem cells in 
rotating-wall vessel bioreactors. Stem Cell Reports 10 300-313. (https:// doi.org/10.1016/j.stemcr.2017.11.001)

Doi D, Morizane A, Kikuchi T, Onoe H, Hayashi T, Kawasaki T, Motono M, Sasai Y, Saiki H, Gomi M et al. 2012 Prolonged maturation culture favors a reduction in the tumorigenicity and the dopaminergic function of human ESC-derived neural cells in a primate model of Parkinson's disease. Stem Cells 30 935-945. (https;//doi.org/10.1002/stem.1060)

Draper JS, Smith K, Gokhale P, Moore HD, Maltby E, Johnson J, Meisner L, Zwaka TP, Thomson JA \& Andrews PW 2004 Recurrent gain of chromosomes $17 q$ and 12 in cultured human embryonic stem cells. Nature Biotechnology 22 53-54. (https://doi.org/10.1038/nbt922)

Duggal G, Warrier S, Ghimire S, Broekaert D, Van der Jeught M, Lierman S, Deroo T, Peelman L, Van Soom A, Cornelissen R et al. 2015 Alternative routes to induce naïve pluripotency in human embryonic stem cells. Stem Cells 33 2686-2698. (https://doi.org/10.1002/stem.2071)

Efthymiou AG, Chen G, Rao M, Chen G \& Boehm M 2014 Self-renewal and cell lineage differentiation strategies in human embryonic stem cells and induced pluripotent stem cells. Expert Opinion on Biological Therapy 14 1333-1344. (https://doi.org/10.1517/14712598.2014.922533)

Folmes CDL, Martinez-Fernandez A, Perales-Clemente E, Li X, McDonald A, Oglesbee D, Hrstka SC, Perez-Terzic C, Terzic A \& Nelson TJ 2013 Disease-causing mitochondrial heteroplasmy segregated within induced pluripotent stem cell clones derived from a MELAS patient. Stem Cells 31 1298-1308. (https://doi.org/10.1002/ stem.1389)

Forsyth NR, Musio A, Vezzoni P, Simpson AHRW, Noble BS \& McWhir J 2006 Physiologic oxygen enhances human embryonic stem cell clonal recovery and reduces chromosomal abnormalities. Cloning and Stem Cells 8 16-23. (https://doi.org/10.1089/clo.2006.8.16)

Fraga AM, Souza de Araújo ÉS, Stabellini R, Vergani N \& Pereira LV 2011 A survey of parameters involved in the establishment of new lines of human embryonic stem cells. Stem Cell Reviews 7 775-781. (https://doi. org/10.1007/s12015-011-9250-x)

Fujikawa T, Oh S, Pi L, Hatch HM, Shupe T \& Petersen BE 2005 Teratoma formation leads to failure of treatment for Type I diabetes using embryonic stem cell-derived insulin-producing cells. American Journal of Pathology 166 1781-1791. (https://doi.org/10.1016/S0002-9440(10)62488-1)

Garber K 2015 RIKEN suspends first clinical trial involving induced pluripotent stem cells. Nature Biotechnology 33 890-891. (https://doi. org/10.1038/nbt0915-890)

Geens M, Mateizel I, Sermon K, De Rycke M, Spits C, Cauffman G, Devroey P, Tournaye H, Liebaers I \& Van de Velde H 2009 Human embryonic stem cell lines derived from single blastomeres of two 4-cell stage embryos. Human Reproduction 24 2709-2717. (https://doi. org/10.1093/humrep/dep262)

Gore A, Li Z, Fung HL, Young JE, Agarwal S, Antosiewicz-Bourget J, Canto I, Giorgetti A, Israel MA, Kiskinis E et al. 2011 Somatic coding mutations in human induced pluripotent stem cells. Nature 471 63-67. (https://doi.org/10.1038/nature09805)

Hanna J, Cheng AW, Saha K, Kim J, Lengner CJ, Soldner F, Cassady JP, Muffat J, Carey BW \& Jaenisch R 2010 Human embryonic stem cells with biological and epigenetic characteristics similar to those of mouse ESCs. PNAS 107 9222-9227. (https://doi.org/10.1073/pnas.1004584107)

Hatakeyama H, Katayama A, Komaki H, Nishino I \& Goto Y 2015 Molecular pathomechanisms and cell-type-specific disease phenotypes of MELAS caused by mutant mitochondrial tRNA(Trp). Acta Neuropathologica Communications 3 52. (https://doi.org/10.1186/s40478-015-0227-x)

Honda A, Hatori M, Hirose M, Honda C, Izu H, Inoue K, Hirasawa R, Matoba S, Togayachi S, Miyoshi H et al. 2013 Naive-like conversion overcomes the limited differentiation capacity of induced pluripotent stem cells. Journal of Biological Chemistry 288 26157-26166. (https:// doi.org/10.1074/jbc.M113.502492)

Hussein SM, Batada NN, Vuoristo S, Ching RW, Autio R, Närvä E, Ng S, Sourour M, Hämäläinen R, Olsson C et al. 2011 Copy number variation and selection during reprogramming to pluripotency. Nature 471 58-62. (https://doi.org/10.1038/nature09871)

Ilic D, Devito L, Miere C \& Codognotto S 2015 Human embryonic and induced pluripotent stem cells in clinical trials. British Medical Bulletin 116 19-27. (https://doi.org/10.1093/bmb/ldv045)

Imreh MP, Gertow K, Cedervall J, Unger C, Holmberg K, Szöke K, Csöregh L, Fried G, Dilber S, Blennow E et al. 2006 In vitro culture conditions favoring selection of chromosomal abnormalities in human
ES cells. Journal of Cellular Biochemistry 99 508-516. (https://doi. org/10.1002/jcb.20897)

Jacobs K, Mertzanidou A, Geens M, Thi Nguyen H, Staessen C \& Spits C 2014 Low-grade chromosomal mosaicism in human somatic and embryonic stem cell populations. Nature Communications 54227. (https://doi.org/10.1038/ncomms5227)

Jacobs K, Zambelli F, Mertzanidou A, Smolders I, Geens M, Nguyen HT, Barbé L, Sermon K \& Spits C 2016 Higher-density culture in human embryonic stem cells results in DNA damage and genome instability. Stem Cell Reports 6 330-341. (https://doi.org/10.1016/j.stemcr.2016.01.015)

Ji J, Ng SH, Sharma V, Neculai D, Hussein S, Sam M, Trinh Q, Church GM, McPherson JD, Nagy A et al. 2012 Elevated coding mutation rate during the reprogramming of human somatic cells into induced pluripotent stem cells. Stem Cells 30 435-440. (https://doi.org/10.1002/stem.1011)

Johannesson B, Sagi I, Gore A, Paull D, Yamada M, Golan-Lev T, Li Z, LeDuc C, Shen Y, Stern S et al. 2014 Comparable frequencies of coding mutations and loss of imprinting in human pluripotent cells derived by nuclear transfer and defined factors. Cell Stem Cell 15 634-642. (https:// doi.org/10.1016/j.stem.2014.10.002)

Kang E, Wang X, Tippner-Hedges R, Ma H, Folmes CDL, Gutierrez NM, Lee Y, Van Dyken C, Ahmed R, Li Y et al. 2016 Age-related accumulation of somatic mitochondrial DNA mutations in adult-derived human ipscs. Cell Stem Cell 18 625-636. (https://doi.org/10.1016/j.stem.2016.02.005)

Keller A, Dziedzicka D, Zambelli F, Markouli C, Sermon K, Spits C \& Geens M 2018 Genetic and epigenetic factors which modulate differentiation propensity in human pluripotent stem cells. Human Reproduction Update 24 162-175. (https://doi.org/10.1093/humupd/ $\mathrm{dm} \times 042)$

Kim K, Zhao R, Doi A, Ng K, Unternaehrer J, Cahan P, Hongguang $\mathbf{H}$, Loh Y, Aryee MJ, Lensch MW et al. 2011 Donor cell type can influence the epigenome and differentiation potential of human induced pluripotent stem cells. Nature Biotechnology 29 1117-1120. (https;// doi.org/10.1038/nbt.2052)

Kim Y, Kim H, Ko UH, Oh Y, Lim A, Sohn J-W, Shin JH, Kim H \& Han YM 2016 Islet-like organoids derived from human pluripotent stem cells efficiently function in the glucose responsiveness in vitro and in vivo. Scientific Reports 6 35145. (https://doi.org/10.1038/srep35145)

Kirk K, Hao E, Lahmy R \& Itkin-Ansari P 2014 Human embryonic stem cell derived islet progenitors mature inside an encapsulation device without evidence of increased biomass or cell escape. Stem Cell Research 12 807-814. (https://doi.org/10.1016/j.scr.2014.03.003)

Klimanskaya I, Chung Y, Becker S, Lu S-J \& Lanza R 2006 Human embryonic stem cell lines derived from single blastomeres. Nature $\mathbf{4 4 4}$ 481-485. (https://doi.org/10.1038/nature05142)

Kretzschmar K \& Clevers H 2016 Organoids: modeling development and the stem cell niche in a dish. Developmental Cell 38 590-600. (https:// doi.org/10.1016/j.devcel.2016.08.014)

Kroon E, Martinson LA, Kadoya K, Bang AG, Kelly OG, Eliazer S, Young H, Richardson M, Smart NG, Cunningham J et al. 2008 Pancreatic endoderm derived from human embryonic stem cells generates glucoseresponsive insulin-secreting cells in vivo. Nature Biotechnology 26 443-452. (https://doi.org/10.1038/nbt1393)

Laflamme MA, Chen KY, Naumova AV, Muskheli V, Fugate JA, Dupras SK, Reinecke H, Xu C, Hassanipour M, Police S et al. 2007 Cardiomyocytes derived from human embryonic stem cells in pro-survival factors enhance function of infarcted rat hearts. Nature Biotechnology 25 1015-1024. (https://doi.org/10.1038/nbt1327)

Lamm N, Ben-David U, Golan-Lev T, Storchová Z, Benvenisty N \& Kerem B 2016 Genomic instability in human pluripotent stem cells arises from replicative stress and chromosome condensation defects. Cell Stem Cell 18 253-261. (https://doi.org/10.1016/j.stem.2015.11.003)

Lancaster MA, Renner M, Martin C-A, Wenzel D, Bicknell LS, Hurles ME, Homfray T, Penninger JM, Jackson AP \& Knoblich JA 2013 Cerebral organoids model human brain development and microcephaly. Nature 501 373-379. (https://doi.org/10.1038/nature12517)

Laurent LC, Ulitsky I, Slavin I, Tran H, Schork A, Morey R, Lynch C, Harness JV, Lee S, Barrero MJ et al. 2011 Dynamic changes in the copy number of pluripotency and cell proliferation genes in human ESCs and iPSCs during reprogramming and time in culture. Cell Stem Cell 8 106-118. (https://doi.org/10.1016/j.stem.2010.12.003)

Lee AS, Tang C, Cao F, Xie X, Van Der Bogt K, Connolly AJ, Robbins RC, Wu JC, Wu JC 2009 Effects of cell number on teratoma formation by 
human embryonic stem cells. Cell Cycle 8 2608-2612. (https://doi. org/10.4161/Cc.8.16.9353)

Lee AS, Tang C, Rao MS, Weissman IL \& Wu JC 2013 Tumorigenicity as a clinical hurdle for pluripotent stem cell therapies. Nature Medicine 19 998-1004. (https://doi.org/10.1038/nm.3267)

Lee JH, Laronde S, Collins TJ, Shapovalova Z, Tanasijevic B, McNicol JD, Fiebig-Comyn A, Benoit YD, Lee JB, Mitchell RR et al. 2017 Lineagespecific differentiation is influenced by state of human pluripotency. Cell Reports 19 20-35. (https://doi.org/10.1016/j.celrep.2017.03.036)

Li G, Xie B, He L, Zhou T, Gao G, Liu S, Pan G, Ge J, Peng F \& Zhong X 2018 Generation of retinal organoids with mature rods and cones from urine-derived human induced pluripotent stem cells. Stem Cell International 2018 1-12. (https://doi.org/10.1155/2018/4968658)

Lim H, Han J, Woo D, Kim S, Kim S, Kang HG \& Kim JH 2011 Biochemical and morphological effects of hypoxic environment on human embryonic stem cells in long-term culture and differentiating embryoid bodies. Molecules and Cells 31 123-132. (https://doi.org/10.1007/s10059-011-0016-8)

Lindvall O 2016 Clinical translation of stem cell transplantation in Parkinson's disease. Journal of Internal Medicine 279 30-40. (https://doi. org/10.1111/joim.12415)

Löser P, Schirm J, Guhr A, Wobus AM \& Kurtz A 2010 Human embryonic stem cell lines and their use in international research. Stem Cells $\mathbf{2 8}$ 240-246. (https://doi.org/10.1002/stem.286)

Lund RJ, Närvä E \& Lahesmaa R 2012 Genetic and epigenetic stability of human pluripotent stem cells. Nature Reviews. Genetics 13 732-744. (https://doi.org/10.1038/nrg3271)

Ma H, Morey R, O'Neil RC, He Y, Daughtry B, Schultz MD, Hariharan M, Nery JR, Castanon R, Sabatini K et al. 2014 Abnormalities in human pluripotent cells due to reprogramming mechanisms. Nature $\mathbf{5 1 1 ( 7 5 0 8 )}$ 177-183. (https: doi.org/10.1038/nature13551)

Mah N, Wang Y, Liao M-C, Prigione A, Jozefczuk J, Lichtner B, Wolfrum K, Haltmeier M, Flöttmann M, Schaefer M et al. 2011 Molecular insights into reprogramming-initiation events mediated by the OSKM gene regulatory network. PLOS ONE 6 e24351. (https://doi.org/10.1371/ journal.pone.0024351)

Maitra A, Arking DE, Shivapurkar N, Ikeda M, Stastny V, Kassauei K, Sui G, Cutler DJ, Liu Y, Brimble SN et al. 2005 Genomic alterations in cultured human embryonic stem cells. Nature Genetics 37 1099-1103. (https:// doi.org/10.1038/ng1631)

Mandai M, Watanabe A, Kurimoto Y, Hirami Y, Morinaga C, Daimon T, Fujihara M, Akimaru H, Sakai N, Shibata Y et al. 2017 Autologous induced stem-cell-derived retinal cells for macular degeneration. New England Journal of Medicine 376 1038-1046. (https://doi.org/10.1056/ NEJMoa1608368)

Masuda S, Miyagawa S, Fukushima S, Sougawa N, Ito E, Takeda M, Saito A \& Sawa Y 2014 Emerging innovation towards safety in the clinical application of ESCs and iPSCs. Nature Reviews. Cardiology 11 553-554. (https://doi.org/10.1038/nrcardio.2014.9-c1)

Mayshar Y, Ben-David U, Lavon N, Biancotti J-C, Yakir B, Clark AT, Plath K, Lowry WE \& Benvenisty N 2010 Identification and classification of chromosomal aberrations in human induced pluripotent stem cells. Cell Stem Cell 7 521-531. (https://doi.org/10.1016/j.stem.2010.07.017)

Mclelland BT, Lin B, Mathur A, Aramant RB, Thomas BB, Keirstead HS, Seiler MJ, Seiler MJ 2018 Transplanted hESC-derived retina organoid sheets differentiate, integrate, and improve visual function in retinal degenerate rats. Investigative Opthalmology and Visual Science $\mathbf{5 9}$ 2586-2603. (https://doi.org/10.1167/iovs.17-23646)

Menasché P, Vanneaux V, Fabreguettes J-R, Bel A, Tosca L, Garcia S, Bellamy V, Farouz Y, Pouly J, Damour O et al. 2014 Towards a clinical use of human embryonic stem cell-derived cardiac progenitors: a translational experience. European Heart Journal 36 743-750. (https:// doi.org/10.1093/eurheartj/ehu192)

Menasché P, Vanneaux V, Hagège A, Bel A, Cholley B, Parouchev A, Cacciapuoti I, Al-Daccak R, Benhamouda N, Blons H et al. 2018 Transplantation of human embryonic stem cell-derived cardiovascular progenitors for severe ischemic left ventricular dysfunction. Journal of the American College of Cardiology 71 429-438. (https://doi.org/10.1016/j. jacc.2017.11.047)

Merkle FT, Ghosh S, Kamitaki N, Mitchell J, Avior Y, Mello C, Kashin S, Mekhoubad S, Ilic D, Charlton M et al. 2017 Human pluripotent stem cells recurrently acquire and expand dominant negative P53 mutations. Nature 545 229-233. (https://doi.org/10.1038/nature22312)
Mfopou JK, Chen B, Sui L, Sermon K \& Bouwens L 2010 Recent advances and prospects in the differentiation of pancreatic cells from human embryonic stem cells. Diabetes 59 2094-2101. (https://doi.org/10.2337/ db10-0439)

Mitsui K, Ide K, Takayama A, Wada T, Irie R \& Kosai K 2015 Conditionally replicating adenovirus prevents pluripotent stem cell-derived teratoma by specifically eliminating undifferentiated cells. Molecular Therapy $\mathbf{2}$ 15026. (https://doi.org/10.1038/mtm.2015.26)

Morizane R, Lam AQ, Freedman BS, Kishi S, Valerius MT \& Bonventre JV 2015 Nephron organoids derived from human pluripotent stem cells model kidney development and injury. Nature Biotechnology 33 1193-1200. (https://doi.org/10.1038/nbt.3392)

Nakajima F, Tokunaga K \& Nakatsuji N 2007 Human leukocyte antigen matching estimations in a hypothetical bank of human embryonic stem cell lines in the Japanese population for use in cell transplantation therapy. Stem Cells 25 983-985. (https://doi. org/10.1634/stemcells.2006-0566)

Nakatsuji N, Nakajima F \& Tokunaga K 2008 HLA-haplotype banking and iPS cells. Nature Biotechnology 26 739-740. (https://doi.org/10.1038/ nbt0708-739)

Nguyen H, Geens M \& Spits C 2013 Genetic and epigenetic instability in human pluripotent stem cells. Human Reproduction Update 19 187-205. (https://doi.org/10.1093/humupd/dms048)

Nguyen HT, Geens M, Mertzanidou A, Jacobs K, Heirman C, Breckpot K \& Spits C 2014 Gain of 20q11.21 in human embryonic stem cells improves cell survival by increased expression of Bcl-xL. Molecular Human Reproduction 20 168-177. (https://doi.org/10.1093/molehr/gat077)

Nichols J \& Smith A 2009 Naive and primed pluripotent states. Cell Stem Cell 4 487-492. (https://doi.org/10.1016/j.stem.2009.05.015)

Ohi Y, Qin H, Hong C, Blouin L, Polo JM, Guo T, Qi Z, Downey SL, Manos PD, Rossi DJ et al. 2011 Incomplete DNA methylation underlies a transcriptional memory of somatic cells in human iPS cells. Nature Cell Biology 13 541-549. (https://doi.org/10.1038/ncb2239)

Okita K, Matsumura Y, Sato Y, Okada A, Morizane A, Okamoto S, Hong H, Nakagawa M, Tanabe K, Tezuka K et al. 2011 A more efficient method to generate integration-free human iPS cells. Nature Methods 8 409-412. (https://doi.org/10.1038/nmeth.1591)

Pagliuca FW, Millman JR, Gürtler M, Segel M, Van Dervort A, Ryu JH, Peterson QP, Greiner D \& Melton DA 2014 Generation of functional human pancreatic B cells in vitro. Cell 159 428-439. (https://doi. org/10.1016/j.cell.2014.09.040)

Perales-Clemente E, Cook AN, Evans JM, Roellinger S, Secreto F, Emmanuele V, Oglesbee D, Mootha VK, Hirano M, Schon EA et al. 2016 Natural underlying mtDNA heteroplasmy as a potential source of intra-person hiPSC variability. EMBO Journal 35 e201694892. (https:// doi.org/10.15252/embj.201694892)

Quintanilla RH, Asprer JST, Vaz C, Tanavde V \& Lakshmipathy U 2014 CD44 is a negative cell surface marker for pluripotent stem cell identification during human fibroblast reprogramming. PLOS ONE 9 e85419. (https://doi.org/10.1371/journal.pone.0085419)

Ravi M, Mitalipova MM, Rao RR, Hoyer DM, Johnson Ja, Meisner LF, Jones KL, Dalton S \& Stice SL 2005 Preserving the genetic integrity of human embryonic stem cells. Nature Biotechnology 23 19-20. (https:// doi.org/10.1038/nbt0105-19)

Renner M, Lancaster MA, Bian S, Choi H, Ku T, Peer A, Chung K \& Knoblich JA 2017 Self-organized developmental patterning and differentiation in cerebral organoids. EMBO Journal 36 1316-1329. (https://doi.org/10.15252/embj.201694700)

Rosner M, Schipany K \& Hengstschläger M 2014 The decision on the 'optimal' human pluripotent stem cell. Stem Cells Translational Medicine 3 553-559. (https://doi.org/10.5966/sctm.2013-0194)

Roy NS, Cleren C, Singh SK, Yang L, Beal MF \& Goldman SA 2006 Functional engraftment of human ES cell-derived dopaminergic neurons enriched by coculture with telomerase-immortalized midbrain astrocytes. Nature Medicine 12 1259-1268. (https://doi.org/10.1038/nm1495)

Schulz TC, Young HY, Agulnick AD, Babin MJ, Baetge EE, Bang AG, Bhoumik A, Cepa I, Cesario RM, Haakmeester C et al. 2012 A scalable system for production of functional pancreatic progenitors from human embryonic stem cells. PLoS ONE 7 e37004. (https://doi.org/10.1371/ journal.pone.0037004)

Schwartz SD, Hubschman J-P, Heilwell G, Franco-Cardenas V, Pan CK, Ostrick RM, Mickunas E, Gay R, Klimanskaya I \& Lanza R 2012 
Embryonic stem cell trials for macular degeneration: a preliminary report Lancet 379 713-720. (https://doi.org/10.1016/S0140-6736(12)60028-2)

Schwartz SD, Regillo CD, Lam BL, Eliott D, Rosenfeld PJ, Gregori NZ, Hubschman J, Davis JL, Heilwell G, Spirn M et al. 2015 Human embryonic stem cell-derived retinal pigment epithelium in patients with age-related macular degeneration and Stargardt's macular dystrophy: follow-up of two open-label phase 1/2 studies. Lancet 385 509-516. (https://doi.org/10.1016/S0140-6736(14)61376-3)

Scotto L, Narayan G, Nandula SV, Arias-pulido H, Subramaniyam S, Schneider A, Kaufmann AM, Wright JD, Pothuri B, Mansukhani M et al. 2008 Identification of copy number gain and overexpressed genes on chromosome arm $20 \mathrm{q}$ by an integrative genomic approach in cervical cancer?: potential role in progression. Genes, Chromosomes and Cance 47 755-765. (https://doi.org/10.1002/gcc.20577)

Shiba Y, Fernandes S, Zhu W-Z, Filice D, Muskheli V, Kim J, Palpant NJ, Gantz J, Moyes KW, Reinecke H et al. 2012 Human ES-cell-derived cardiomyocytes electrically couple and suppress arrhythmias in injured hearts. Nature 489 322-325. (https://doi.org/10.1038/nature11317)

Simonson OE, Domogatskaya A, Volchkov P \& Rodin S 2015 The safety of human pluripotent stem cells in clinical treatment. Annals of Medicine 47 370-380. (https://doi.org/10.3109/07853890.2015.1051579)

Song WK, Park K-M, Kim H-J, Lee JH, Choi J, Chong SY, Shim SH, Del Priore LV \& Lanza R 2015 Treatment of macular degeneration using embryonic stem cell-derived retinal pigment epithelium: preliminary results in Asian patients. Stem Cell Reports 4 860-872. (https://doi. org/10.1016/j.stemcr.2015.04.005)

Sugiura M, Kasama Y, Araki R, Hoki Y, Sunayama M, Uda M, Nakamura M, Ando S \& Abe M 2014 Induced pluripotent stem cell generationassociated point mutations arise during the initial stages of the conversion of these cells. Stem Cell Reports 2 52-63. (https://doi.org/10.1016/j. stemcr.2013.11.006)

Sui L, Mfopou JK, Chen B, Sermon K \& Bouwens L 2013 Transplantation of human embryonic stem cell-derived pancreatic endoderm reveals a site-specific survival, growth, and differentiation. Cell Transplantation 22 821-830. (https://doi.org/10.3727/096368912X636812)

Tabach Y, Kogan-Sakin I, Buganim Y, Solomon H, Goldfinger N, Hovland R, Ke X-S, Oyan AM, Kalland K-H, Rotter V et al. 2011 Amplification of the $20 \mathrm{q}$ chromosomal arm occurs early in tumorigenic transformation and may initiate cancer. PLOS ONE 6 e14632. (https://doi.org/10.1371/ journal.pone.0014632)

Tachibana M, Amato P, Sparman M, Gutierrez NM, Tippner-Hedges R, Ma H, Kang E, Fulati A, Lee H-S, Sritanaudomchai H et al. 2013 Human embryonic stem cells derived by somatic cell nuclear transfer. Cell 153 1228-1238. (https://doi.org/10.1016/j.cell.2013.05.006)

Takahashi K \& Yamanaka S 2006 Induction of pluripotent stem cells from mouse embryonic and adult fibroblast cultures by defined factors. Cell 126 663-676. (https://doi.org/10.1016/j.cell.2006.07.024)

Takahashi K, Tanabe K, Ohnuki M, Narita M, Ichisaka T, Tomoda K \& Yamanaka S 2007 Induction of pluripotent stem cells from adult human fibroblasts by defined factors. Cell 131 861-872. (https://doi. org/10.1016/j.cell.2007.11.019)

Takasato M, Er PX, Becroft M, Vanslambrouck JM, Stanley EG, Elefanty AG \& Little MH 2014 Directing human embryonic stem cell differentiation towards a renal lineage generates a self-organizing kidney. Nature Cell Biology 16 118-126. (https://doi.org/10.1038/ncb2894)

Tang Y-C, Williams BR, Siegel JJ \& Amon A 2011 Identification of aneuploidy-selective antiproliferation compounds. Cell 144 499-512. (https://doi.org/10.1016/j.cell.2011.01.017)

Tesar PJ, Chenoweth JG, Brook FA, Davies TJ, Evans EP, Mack DL, Gardner RL \& McKay RDG 2007 New cell lines from mouse epiblast share defining features with human embryonic stem cells. Nature 448 196-199. (https://doi.org/10.1038/nature05972)

Tiemann U, Wu G, Marthaler AG, Schöler HR \& Tapia N 2016 Epigenetic aberrations are not specific to transcription factor-mediated reprogramming. Stem Cell Reports 6 35-43. (https://doi.org/10.1016/j. stemcr.2015.11.007)

Trounson A \& DeWitt ND 2016 Pluripotent stem cells progressing to the clinic. Nature Reviews. Molecular Cell Biology 17 194-200. (https://doi. org/10.1038/nrm.2016.10)

Wang YK, Zhu WW, Wu MH, Wu YH, Liu ZX, Liang LM, Sheng C, Hao J, Wang L, Li W et al. 2018 Human clinical-grade parthenogenetic ESC-derived dopaminergic neurons recover locomotive defects of nonhuman primate models of Parkinson's disease. Stem Cell Reports 11 171-182. (https://doi.org/10.1016/j.stemcr.2018.05.010)

Warrier S, Van der Jeught M, Duggal G, Tilleman L, Sutherland E, Taelman J, Popovic M, Lierman S, Chuva De Sousa Lopes S, Van Soom A et al. 2017 Direct comparison of distinct naive pluripotent states in human embryonic stem cells. Nature Communications 8 15055. (https:// doi.org/10.1038/ncomms15055)

Weinberger L, Ayyash M, Novershtern N \& Hanna JH 2016 Dynamic stem cell states: naive to primed pluripotency in rodents and humans. Nature Reviews. Molecular Cell Biology 17 155-169. (https://doi.org/10.1038/ nrm.2015.28)

Wolf DP, Morey R, Kang E, Ma H, Hayama T, Laurent LC \& Mitalipov S 2017 Concise review: embryonic stem cells derived by somatic cell nuclear transfer: a horse in the race? Stem Cells 35 26-34. (https://doi. org/10.1002/stem.2496)

Yoshihara M, Hayashizaki Y \& Murakawa Y 2017a Genomic instability of iPSCs: challenges towards their clinical applications. Stem Cell Reviews and Reports 13 7-16. (https://doi.org/10.1007/s12015-016-9680-6)

Yoshihara M, Araki R, Kasama Y, Sunayama M, Abe M, Nishida K, Kawaji H, Hayashizaki Y \& Murakawa Y 2017b Hotspots of de novo point mutations in induced pluripotent stem cells. Cell Reports 21 308-315. (https://doi.org/10.1016/j.celrep.2017.09.060)

Young MA, Larson DE, Sun CW, George DR, Ding L, Miller CA, Lin L, Pawlik KM, Chen K, Fan X et al. 2012 Background mutations in parental cells account for most of the genetic heterogeneity of induced pluripotent stem cells. Cell Stem Cell 10 570-582. (https://doi.org/10.1016/j. stem.2012.03.002)

Zambelli F, Mertens J, Dziedzicka D, Sterckx J, Markouli C, Keller A, Tropel P, Jung L, Viville S, Van de Velde H et al. 2018 Random mutagenesis, clonal events and embryonic or somatic origin determine the mitochondrial DNA variant type and load in human pluripotent stem cells. Stem Cell Reports 11 102-114. (https://doi.org/10.1016/j. stemcr.2018.05.007)

Zhan X, Dravid G, Ye Z, Hammond H, Shamblott M, Gearhart J \& Cheng L 2004 Functional antigen- presenting leucocytes derived from human embryonic stem cells in vitro. Lancet 364 163-171. (https://doi. org/10.1016/S0140-6736(04)16629-4)

Received 5 June 2018

First decision 23 July 2018

Revised manuscript received 16 August 2018

Accepted 12 September 2018 